\title{
FINDING THE 'WORLD’ IN BIBLICAL STUDIES: GOD-TALK, CULTURE AND HERMENEUTICS IN THE STUDY (AND TEACHING) OF FAITH
}

\author{
Gerald A Klingbeil \\ Hebrew Bible and Ancient Near Eastern Studies \\ Theological SeminaryAdventist International Institute of Advanced Studies \\ Silang, Cavite, Philippines
}

\begin{abstract}
This study seeks to describe the elusive links between world, theology, and faith by means of a concise chronological review of how historically these crucial elements interacted and what role empirical methods played in this interaction. Following this, particular focus will be given to one current empirical method of interpreting Scripture, i.e., cultural criticism. Recognizing the importance of biblical metaphor to the hermeneutical enterprise, the study will review how cultural criticism relates to one important biblical metaphor, i.e., God-as-a-warrior. In conclusion, it is argued that biblical hermeneutics need to use a model of interpretation that emanates from the Bible itself, instead of employing primarily a model that is foreign to the Bible. This, in turn, will inform the crucial issue of the interaction between world, theology and faith and their relationship to empirical methods.
\end{abstract}

Key Words:Hermeneutics, Biblical Interpretation, Cultural Criticism, God-as-a-Warrior, Metaphor, Theology, Faith

\begin{abstract}
Introduction
The concept of the world - hated or embraced - has historically been intricately entwined in Christian hermeneutics, pastoral work, and missiological approaches. This study will focus on describing and understanding the elusive links between world, theology, and faith and their importance for working in the field of Biblical Studies. ${ }^{1}$ To begin with, this study will seek to graphically and conceptually define and describe the interaction between these three key terms. Particular focus will be given to one current empirical method of interpreting Scripture, namely cultural criticism. After a brief introduction to this "postmodern" approach of reading the Bible, I will link its importance to the discussion of the three key terms of this study, i.e., world, theology, and faith. Recognizing the importance of biblical metaphor to the hermeneutical enterprise, this study will see how cultural criticism approaches and interacts with the one particular metaphor, which is extremely important in the Hebrew Bible, but also present (even though to a lesser degree) in the New Testament, i.e., God as a warrior. I have chosen this particular metaphor

This study is a revised version of the March 29, 2007, opening plenary session by the same title presented at the congress of the European Theology Teachers' Convention, organized by European institutions of higher learning of the Seventh-day Adventist Church, and held at Theologische Hochschule Friedensau, Germany. The title of the conference was 'World' in Theology: Empirical Dimensions in the Study of Faith. At some junctions of this study, the oral nature of the presentation may still be visible and hopefully make for a better reading. I would also like to express my appreciation to the two anonymous readers of the Scriptura editorial board whose comments helped to make this study more focused.
\end{abstract}


because it contains and communicates a fair amount of theology and interacts with some burning concerns of cultural criticism practitioners (such as "holy war" or "just wars"). In the conclusion I will argue for a biblical hermeneutics that emanates from the Bible itself and that guides the important interaction between world, theology and faith.

\section{World, Theology and Faith: A Triangle}

Seeing that a "picture is worth a 1,000 words" I will attempt to demonstrate the relationship and interaction between world, theology, and faith graphically in the following figure.

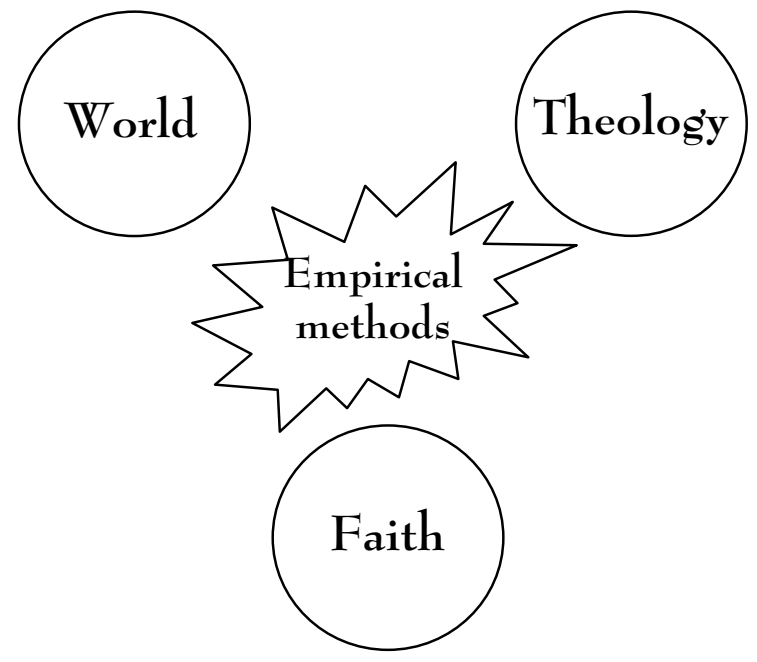

As can be seen, links or arrows connecting the three main ingredients of equation have not been included. Also, the empirical methods seem to be disconnected. I would suggest that the arrows linking this triangle have varied in the past. For example, the world (Hebr. אר,

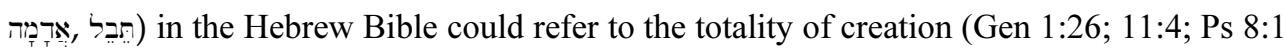
[ET 2]; etc.) or it could just mean a portion of this total, namely the land of Canaan which was to be the place where God's promises and blessings could become visible (Gen 12:1-3). ${ }^{2}$ The world was the platform for any interaction with God, and faith and theology developed in it. The holistic nature of the anthropology of the Hebrew Bible (including the importance and all-pervasiveness of community), ${ }^{3}$ together with its all-

See Michael A Grisanti, “אדרָהד" NIDOTTE 1:269-74; Christopher JH Wright, "אריץ" NIDOTTE 1:518-24; idem, "תברל" NIDOTTE 4:272-73.

3 Helpful more recent discussions of the anthropology of the Hebrew Bible (in chronological order) include Antonio Rodríguez Carmona, "El hombre en el judaísmo," Estudios Bíblicos 57 (1999):589-611; Michaela Geiger and Stefanie Schäfer-Bossert, "Körperkonzepte im Ersten Testament - Aspekte einer Feministischen Anthropologie. Eine Einführung," in Körperkonzepte im Ersten Testament. Aspekte einer Feministischen Anthropologie (ed. Hedwig-Jahnow-Forschungsprojekt; Stuttgart: Verlag W Kohlhammer, 2003), 10-28; Anna Kiesow, "Auf der Suche nach dem Menschen. Forschungsüberblick zu 'Anthropologien des Alten Testaments'," in Körperkonzepte im Ersten Testament. Aspekte einer Feministischen Anthropologie (ed. Hedwig-Jahnow-Forschungsprojekt; Stuttgart: Verlag W Kohlhammer, 2003), 29-41. Erhard Blum, "Von Gottesunmittelbarkeit zu Gottähnlichkeit: Überlegungen zur theologischen Anthropologie der Paradieserzählung," in Gottes Nähe im Alten Testament (ed. Gönke Eberhardt and Kathrin Liess; Stuttgarter Bibelstudien 202; Stuttgart: Verlag Katholisches Bibelwerk, 2004), 9-29; and most recently Bernd Janowski, "Der Mensch im alten Israel. Grundfragen alttestamentlicher Anthropologie," Zeitschrift für Theologie und Kirche 102 (2005):143-75. 
conviction of divine physical creation ${ }^{4}$ made the world into the stage where all physical and (more limited) also metaphysical interaction happened. The world (and with it matter) was not considered to be bad or evil as in later centuries due to the influence of Greek philosophical thought. While the concept of the land (esp. the Promised Land) is indeed

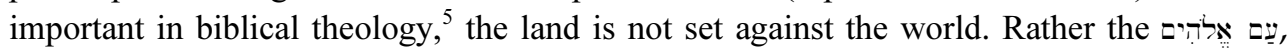
"people of God," (e.g., 2 Sam 14:13) or the יטֵ : יהודה, "people of YHWH" (Num 11:29; 17:6; Judg 5:11; etc.) are often set against the nations, thus emphasizing the importance of family, clan, and tribe for biblical theology and metaphor. ${ }^{6}$ YHWH, however, does not ignore the nations, as can be easily seen in the significant space that the prophets of the Hebrew Bible dedicated to these nations. Paul Raabe has suggested that the prophetic texts of the Hebrew Bible contain about $14 \%$ of messages directed to the nations (close and far off) surrounding Israel, i.e., the "larger world" of the ancient Near East. ${ }^{7}$ The international dimension of the message of the Hebrew Bible seems to reflect a larger divine covenant with humanity which is initiated by God after the flood (Gen 9) and involves certain principles of rightful living which the creator God requires of his creation. In other words, the oracles against the nations remind the readers of universal justice and social responsibility that created beings owe the creator. In biblical thinking Israel is often described as YHWH's (firstborn) son (Exod 4:22; Deut 14:1; 32:5, 19; Isa 1:2; 43:6; 45:11; $63: 8$; Jer $3: 14,19,22$; Hos $2: 1 ; 11: 1)$. The reference to the firstborn clearly highlights issues of status and function, but could also suggests - by implication - that there are other "sons," some of which have already appeared in the table of nations in Gen 10:1-32. It would seem that the prophets understood this universal aspect of sonship and thus included messages to the wayward sons of YHWH in their messages to Israel and/or Judah. Theology

4 William H Bellinger, "Maker of Heaven and Earth: The Old Testament and Creation Theology," Southwestern Journal of Theology 32.2 (1990):27-35.

5 Compare, for example, Walter Brueggemann, The Land: Place as Gift, Promise, and Challenge in Biblical Faith (Overtures to Biblical Theology; Philadelphia: Fortress, 1977), Paul Benjamin, "The Theology of Land in the Book of Joshua" (PhD diss., Lutheran School of Theology, 1986), Christopher JH Wright, God's People in God's Land: Family, Land and Property in the Old Testament (Grand Rapids: Eerdmans, 1990) or Norman C Habel, The Land is Mine: Six Biblical Land Ideologies (Overtures to Biblical Theology; Minneapolis.: Fortress, 1995).

6 In a review of the metaphor map of the Epistle to the Ephesians I have argued that the family metaphor is indeed a highly significant element for the discussion of NT ecclesiology. Compare Gerald A Klingbeil, "Metaphors and Pragmatics: An Introduction to the Hermeneutics of Metaphors in the Epistle to the Ephesians," Bulletin for Biblical Research 16 (2006):273-93. Elsewhere, I have also suggested that this family metaphor may function as a link between an "ecclesiology" of the Hebrew Bible and the New Testament. Cf. Gerald A Klingbeil, "The 'Church' in the Old Testament: Systematic, Linguistic, and Metaphor Perspectives," Journal of Asia Adventist Seminary 9 (2006):3-23.

7 Paul R Raabe, "Why Prophetic Oracles Against the Nations?," in Fortunate the Eyes That See. Essays in Honor of David Noel Freedman in Celebration of His Seventieth Birthday (ed. Astrid B Beck et al.; Grand Rapids: Eerdmans, 1995), 237, provides a useful table tabulating the percentage of the oracles against the nations (OAN) in the prophetic texts of the Hebrew Bible. Out of the 2,047 words of the book of Amos 214 $(=10.5 \%)$ are dedicated to the OAN. Isaiah has a ratio of $14.2 \%$, Jeremiah $14.9 \%$, Ezekiel $15 \%$, etc. Over the past years, much research has been done concerning the reason of the OAN in the prophetic literature, for example, John N Oswalt, "The Nations in Isaiah: Friend or Foe; Servant or Partner," Bulletin for Biblical Research 16 (2006):41-51; J Severino Croatto, "The 'Nations' in the Salvific Oracles of Isaiah," Vetus Testamentum 55 (2005):143-61; Menahem Haran, "The Place of the Prophecies against the Nations in the Book of Jeremiah," in Emanuel. Studies in Hebrew Bible, Septuagint and Dead Sea Scrolls in Honor of Emanuel Tov (ed. Shalom M Paul et al.; VTSup 94; Leiden: Brill, 2003), 699-706; Karl Möller, "Words of (In-)evitable Certitude? Reflections on the Interpretation of Prophetic Oracles of Judgment," in After Pentecost: Language and Biblical Interpretation (ed. Craig G Bartholomew, Colin JD Greene and Karl Möller; The Scripture and Hermeneutics Series 2; Grand Rapids: Zondervan; Carlisle, UK: Paternoster, 2001), $352-86$. 
and faith are necessary and relevant elements in the equation of world, theology, and faith during the time of the Hebrew Bible. Empirical methods did not seem to play much of a role. Rather, it was the faith presupposition that informed the conceptual understanding of the world and theology. It should also be noted that theology and faith were not necessarily clearly divided areas. Instead, they seem to have been complementary.

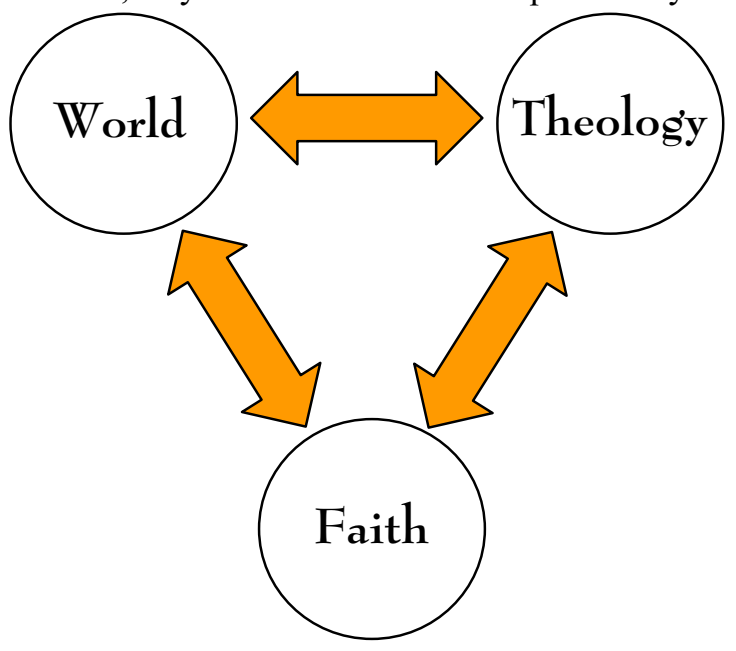

In the New Testament and most likely due to Hellenistic influence, the world concept begins to change. A number of Greek terms are used in relationship to the physical and

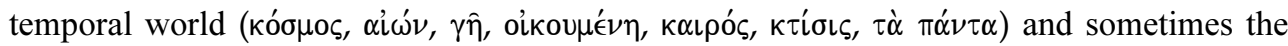
overlap between the physical and the temporal world counterposes two "worlds" or "ages". This age/world 8 is evil (Gal 1:4) and is ruled by the "elemental spirits of this world" (Gal 4:3, 9; Col 2:8, 20). Thus, a future new world/age is envisioned which implies the fulfillment of God's purpose and promises (Eph 1:21; 2:7; Rom 8:18-25; 1 Cor 15:20-28). Returning to our present figure it would seem that in the New Testament and also in the early Christian church the dichotomy between world and faith community becomes increasingly prominent. This may have been due to the fact that the Christian community rapidly moved from a group marked by ethnic links (i.e., one people, one land, under one God, which is reflected in the declaration of independence of the USA) to a community of believers that transcended ethnic and social boundaries and, thus, was more vulnerable to external pressures from the world surrounding it. This world becomes the object of mission of the nascent Christian church, which is marked by an arrow going only in one direction from faith to the world. Theological thinking was developing rapidly in this time, due to the many issues emerging from the cultural and ethnic diversity. A point in case is the NT's dealings with the ritual of the Hebrew Bible. As can be seen in the heated debate during the Jerusalem council (Acts 15) the church is struggling to interact theologically with the ritual requirements of the Hebrew Bible, which in turn required the conscious reflection about hermeneutical method(s). However, these nascent empirical methods were always developed through the lens of faith. There is no arrow between the world and theology. The

8 See for the link between this world and this age 1 Cor 3:19; 5:10. I am basing my comments here on John Painter, "World, Cosmology," in Dictionary of Paul and His Letters (ed. Gerald F Hawthorne et al.; Downers Grove: InterVarsity, 1993), 979-82. 
early NT church was not interested in interacting with the world on a theoretical or philosophical basis. Paul engaged Greek rhetoric and philosophy for one express purpose: "I have become all things to all men, that I might by all means save some" (1 Cor 9:22). The purpose of the use of empirical methods in the early church was clearly missiological.

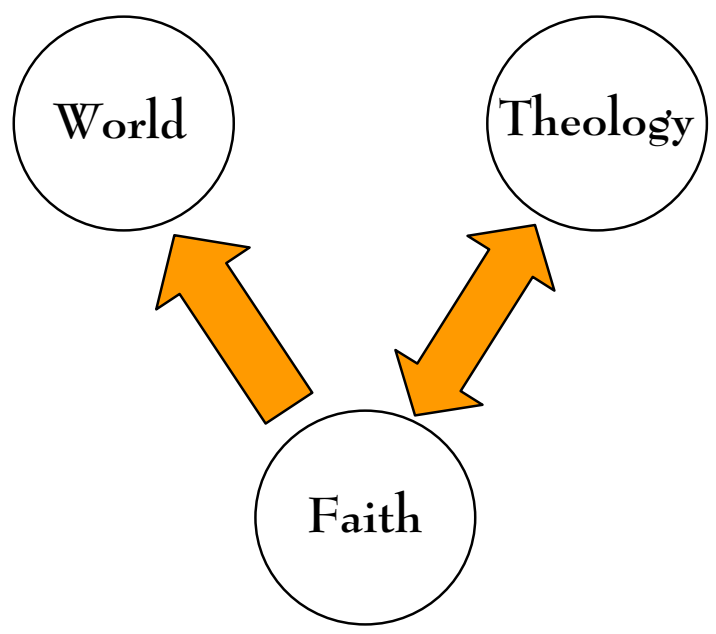

Due to space limitations I will pass over more than 1,500 years, into the modern age that begins with the French Revolution. ${ }^{9}$ The French Revolution, as the culminating point of the Age of Enlightenment at the end of the 18th century, marked an important turning point in biblical hermeneutics. It not only caused tremendous changes in worldview and political outlook, but also resulted in changed paradigms affecting every conceivable area of human knowledge. Of particular interest is the significant influence it had on traditional biblical interpretation and the overall approach to hermeneutics. ${ }^{10}$ The Enlightenment emphasized humanity's inherent reasoning capacity. It criticized external authorities such as the Bible, the church, and the state. Besides its fundamental criticism of religion and the concept of revelation, it also "introduced new methods and new ways of thinking in philosophy, history, and science; evoked new themes, forms, and media in literature; and to a large extent shaped the face of the modern world." "11 Biblical hermeneutics received an important impetus in that period, owing to the fact that scholars recognized (a) the importance of worldview and presuppositions, ${ }^{12}$ and (b) the introduction of new methods of reading Scripture that consciously tried to bracket out issues of inspiration or revelation and thus proposed a reading of the biblical text as any other text. ${ }^{13}$ As a result an impressive array of

$9 \quad$ The following ideas have been taken from my volume dealing with biblical ritual. Cf. Gerald A Klingbeil, Bridging the Gap: Ritual and Ritual Texts in the Bible (Bulletin for Biblical Research Supplements 1; Winona Lake: Eisenbrauns, 2007), esp. chapter 5.

10 A concise introduction to the Age of Enlightenment (German Die Aufklärung) can be found in Colin Brown, "Enlightenment, The," in Evangelical Dictionary of Theology (ed. Walter A Elwell; Grand Rapids: Baker, 1984), 355-57; also more recently Norbert Rath, "Enlightenment," in The Encyclopledia of Christianity (ed. Erwin Fahlbusch et al.; transl. Geoffrey W Bromiley; Grand Rapids: Eerdmans/Leiden: Brill, 2001), 2:95-98.

11 Rath, "Enlightenment," 95.

12 David K Naugle, Worldview: The History of a Concept (Grand Rapids: Eerdmans, 2002), 310-21.

13 See here Roy A Harrisville and Walter Sundberg, The Bible in Modern Culture. Theology and HistoricalCritical Method from Spinoza to Käsemann (Grand Rapids: Eerdmans, 1995), 10-31, who speak of a "war of worldviews" between pre-critical and historical-critical biblical scholarship. 
new hermeneutical approaches dominated the scientific study of the Bible, including historical criticism, source criticism, form criticism, tradition-historical criticism, and redactional criticism. ${ }^{14}$

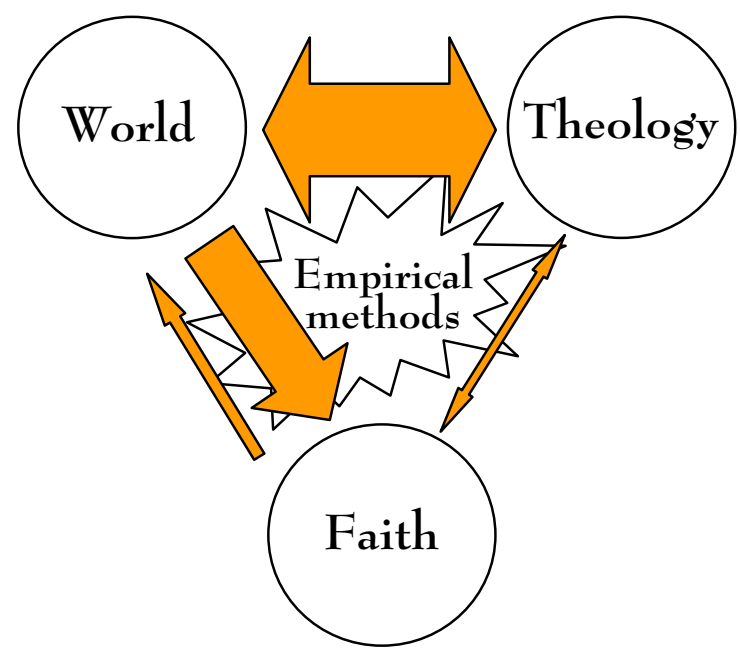

The figure has changed considerably. For the first time we find the empirical methods right in the center of the triangle. The growing importance of reason and critical thinking in the study of the physical phenomena has led scholars to emphasize these methods. The arrow linking the world with theology is not only present but clearly dominates the triangle. The world and the methodical and "unrestrained" thinking about God are communicating and by means of empirical methods are able to renegotiate their relationship apart from faith. Faith is influenced by the world, which has resulted in a changed worldview where God or any supernatural power that cannot be verified by empirical methods does not have a place. Darwin's principle of evolution permeates every scientific discipline, including also theology. This fact can be fairly easily demonstrated by looking at Julius Wellhausen's work. His evolutionary reconstruction of the Pentateuch's literary history was in turn employed to reconstruct the historical course of Israel's religious development. As a matter of fact his desire to describe the history of Israelite-Jewish religion prompted him to work first on the development of the literary data. This should be seen as a tool to a particular end. Wellhausen's influential work Prolegomena to the History of Ancient Israel ${ }^{15}$ contained a detailed reconstruction of the major religious and political institutions of ancient Israel, suggesting an evolutionary process whereby simple forms of religion became increasingly elaborate and complex. The interaction between faith and theology was

14 An accessible introduction to the different hermeneutical approaches, including their presuppositions, main tools, and major representatives can be found in Steven L McKenzie and Stephen R Heynes, eds., To Each Its Own Meaning. An Introduction to Biblical Criticisms and Their Application (rev. ed.; Louisville: Westminster John Knox, 1999), 17-121. A detailed and critical analysis of the presuppositions and epistemological foundations of these methodologies can be found in Raúl Kerbs, "El método histórico-crítico en teología: en busca de su estructura básica y de las interpretaciones filosóficas subyacentes (parte I)," DavarLogos 1 (2002):105-23; idem, "El método histórico-crítico en teología: en busca de su estructura básica y de las interpretaciones filosóficas subyacentes (parte II)," DavarLogos 2 (2003):1-27.

15 Julius Wellhausen, Prolegomena to the History of Ancient Israel (Edinburgh: A and C Black, 1885; reprint. Gloucester, Mass: Peter Smith, 1973) is a translation of revised edition of his earlier Geschichte Israels I, published in 1878 . 
becoming increasingly insignificant. As a result of the strong emphasis on rationalism and critical thinking theology disassociated itself from Seminaries. During the later part of modernism this led to an increase of departments of religions at universities which become more and more secular, while at the same time Seminaries are considered to be the hatching ground of fledgling pastors and priests, who minister to a decreasing population of Christian believers.

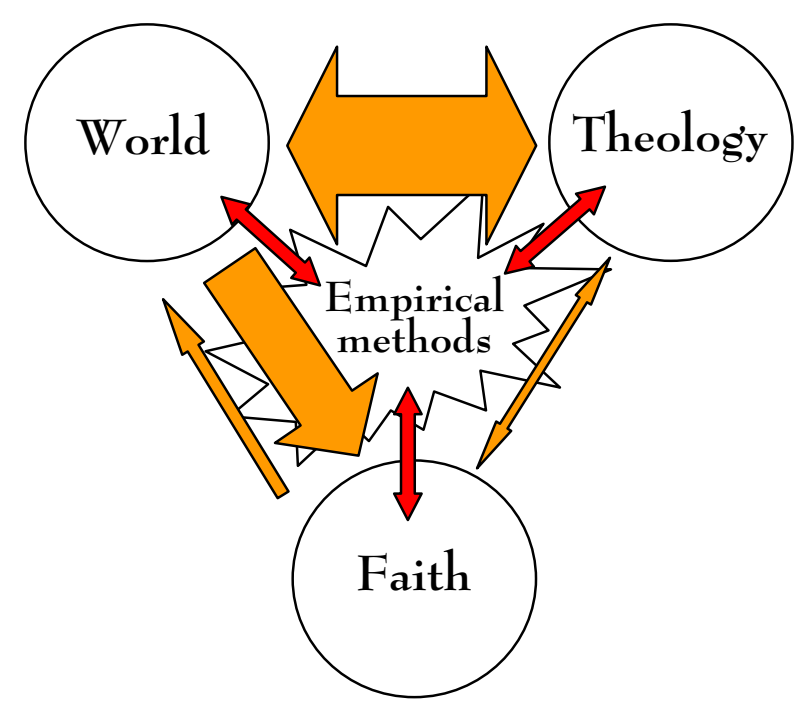

At present, in Western Europe and to a certain degree also in the USA modernism has been replaced by postmodernism, a change which has also profoundly affected the triangle of world, theology, and faith. Individualism and a lack of absolutes question even the most basic element of Christian faith and doctrine as can be easily seen in Philip Turner's remarks concerning the Ten Commandments in the Church in a postmodern Age. ${ }^{16}$ Ethical absolutes are questioned, not only in the "world" but often more so inside the Christian community. ${ }^{17}$ Objectivity, one of the main-stays of modernist ideology, is questioned and challenged. Similar to modernist's rejection of the divine from the sciences, postmodernism

16 Philip Turner, "The Ten Commandments in the Church in a Postmodern World," in I Am the Lord Your God. Christian Reflections on the Ten Commandments (ed. Carl E Braaten and Christopher R Seitz; Grand Rapids: Eerdmans, 2005), 3-17.

17 See here the enlightening studies of Carlos H Cerdá, "Relación entre Laodicea y la sociedad posmoderna: efectos en la iglesia," in Pensar la iglesia hoy: hacia una eclesiología adventista. Estudios teológicos presentados durante el IV Simposio Bíblico-Teológico Sudamericano en honor a Raoul Dederen (ed. Gerald A Klingbeil, Martin G Klingbeil and Miguel Ángel Núñez; Libertador San Martín, Argentina: Editorial Universidad Adventista del Plata, 2002), 377-88. The issue of the relationship between the personal faith commitment and the scholar living in a postmodern society has been lucidly discussed in Mary Hesse, "How to Be a Postmodernist and Remain a Christian: A Response to Nicholas Wolterstorff," in After Pentecost: Language and Biblical Interpretation (ed. Craig G Bartholomew, Colin JD Greene and Karl Möller; The Scripture and Hermeneutics Series 2; Grand Rapids: Zondervan/Carlisle, UK: Paternoster, 2001), 91-96. Cf. also Stanley J Grenz, "Christian Integrity in a Postmodern World (Theological Ethics)," in New Dimensions in Evangelical Thought. Essays in Honor of Millard J Erickson (ed. David S Dockery; Downers Grove: InterVarsity, 1998), 374-410; Theodore A Turnau III, "Speaking in a Broken Tongue: Postmodernism, Principled Pluralism, and the Rehabilitation of Public Moral Discourse," Westminster Theological Journal 56 (1994):345-77; and Alister E McGrath, "The Challenge of Pluralism for the Contemporary Christian Church," Journal of the Evangelical Theological Society 35 (1992):361-73. 
too doubts the divine as a relevant category for human interaction. However, postmodernist's lack of absolutes, does provide for inter-religious dialogue. "If it is right for you, please be my guest." While the main arrows have not been changed, three new connectors have been added to the figure (appearing in red). Empirical methods are in constant interaction with world, theology, and also faith. Assured methodologies and results of the past are being challenged. ${ }^{18}$ New methodologies emerge, resulting in new questions that are being asked and new approaches that are pioneered. Scholarship is challenged to be "relevant" and leave the ivory tower of academia. It is here that culture has crystallized as one of the key perspectives (or lenses) employed by empirical methods to interact between the world, theology, and faith. In the following section cultural criticism will be defined. This method of reading the Bible is comparatively new and has many distinct forms and shapes. It employs different terminology and emphasis, but ultimately focuses on culture as the looking glass through which reality has to be viewed. ${ }^{19}$

\section{Cultural Criticism and Hermeneutics: An Appraisal of Origin, Possible Pitfalls and Possibilities}

Werner Jeanrond has defined cultural criticism as focusing upon:

...the cultural role of the Bible... calling it a "classic" text which bears an excess and permanence of meaning, yet always resists definitive interpretations. As such, it can function as a means of "interruption" in the cultural process, provided its interpreters are open to disclosing the instances of truth contained in it. Paul Knitter and Hans Küng have advocated the perspective of the interreligious dialogue as a necessary complement to any inner-religious approach to understanding these texts. Such a wider approach to the Scriptures moved by questions of the history and the comparative study of religions will also be able to point out such ideological dimensions within the biblical texts as, for instance, anti-feminist and anti-semitic attitudes. ${ }^{20}$

While this definition leaves some specific methodological issues and questions unanswered it provides an interesting point of departure for a definition of cultural criticism. Several aspects should be noted. First, cultural criticism has a historical focus, i.e., it seeks to describe the cultural role of the Bible throughout its existence and - obviously - also in

18 A good example of this can be seen in critical evaluation of the supposed consensus in the critical study of the Pentateuch. Compare here, in chronological order Rolf Rendtorff, "The Paradigm is Changing: Hopes - and Fears," Biblical Interpretation 1 (1993):34-53; Gordon J Wenham, "Method in Pentateuchal Source Criticism," Vetus Testamentum 41 (1991):84-109; Rolf Rendtorff, "Directions in Pentateuchal Studies," Currents in Research: Biblical Studies 5 (1997):43-65; Christian Frevel, "Kein Ende in Sicht? Zur Priestergrundschrift im Buch Levitikus," in Levitikus als Buch (ed. Heinz-Josef Fabry and Hans-Winfried Jüngling; Bonner Biblische Beiträge 119; Berlin-Bodenheim b. Mainz: Philo, 1999), 85-123; Gerald A Klingbeil, "Historical Criticism," in Dictionary of the Old Testament: Pentateuch (ed. T Desmond Alexander and David W Baker; A Compendium of Contemporary Biblical Scholarship; Downers Grove: InterVarsity, 2003), 401-20; Georg Fischer, "Zur Lage der Pentateuchforschung," Zeitschrift für die alttestamentliche Wissenschaft 115 (2003):608-16; and Richard Elliott Friedman, "An Essay on Method," in Le-David Maskil. A Birthday Tribute for David Noel Freedman (ed. Richard Elliott Friedman and William HC Propp; Biblical and Judaic Studies from the University of California, San Diego 9; Winona Lake: Eisenbrauns, 2004), 1-15.

19 It is interesting to see scholars from the two-thirds world (such as Africa) interacting with cultural criticism. See, for example, Musimbi Kanyoro, "Cultural Hermeneutics: An African Contribution," in Other Ways of Reading: African Women and the Bible (ed. Musa W Dube; Global Perspectives on Biblical Scholarship 2; Atlanta: Society of Biblical Literature/Geneva: WCC Publications, 2001), 101-13. More recently, I have reviewed the importance and also pitfalls of cultural criticism in a detailed way. The following comments draw from that earlier study. Cf. Gerald A Klingbeil, "Cultural Criticism and Biblical Hermeneutics: Definition, Origins, Benefits, and Challenges,” Bulletin for Biblical Research 15 (2005):261-77.

20 Werner G Jeanrond, "Interpretation, History of," $A B D$ 3:442-43. 
contemporary society and culture. This historical focus coincides with Telford's categorization of this specific hermeneutical approach, classifying it in his taxonomy of methods and approaches in the field of Biblical Studies with methods predominantly concerned with historical aspects. ${ }^{21}$ Second, meaning is determined by cultural realities and there exists no definitive interpretation. Third, cultural criticism provides a starting point for inter-religious dialogue, but at the same time supplies needed inner-religious feedback to better understand Scripture. Fourth, it supposedly can function as a means to profile ideological dimensions within the biblical text.

Unfortunately, a closer look at the budding field of cultural criticism reveals oftenopposing positions. It is clear that this is an emerging methodology that has not yet solidified into some type of orthodoxy. Even on the level of nomenclature one encounters the lack of unity.

A growing number of journals focusing upon cultural issues and Scripture are being published including Holy Land Studies: A Multidisciplinary Journal (ISSN 1474-9475 and published by Sheffield Academic Press/Continuum), Biblicon: Bible, Media and Culture (Sheffield Academic Press), Semeia (ISSN 0095-571X and published by the Society of Biblical Literature, although it has ceased publication as a journal recently and will only continue as a series), and Biblical Interpretation: A Journal of Contemporary Approaches (ISSN 0927-2569 and published by Brill Academic Publisher).

Additionally, a bewildering number of monograph series are dedicated to studies involving culture and Scripture and thus, could be seen as part of the general trend towards cultural criticism. Some of these series include Bible and Postcolonialism; Bible in the 21st Century; Controversies in the Study of Religion; Gender, Culture, Theory; Issues in Contemporary Religion; Religion and the Arts; Themes in Religious Studies and Writing Past Colonialism, all published by Sheffield Academic Press/Continuum. The Society of Biblical Literature also includes several sections, groups, seminars or consultations that involve cultural criticism, such as "African-American Biblical Hermeneutics", "Bible and Cultural Studies", "Bible and Ancient and Modern Media", "Ideological Criticism, John's Apocalypse and Cultural Contexts Ancient and Modern", "Ancient Fiction and Early Christian and Jewish Narrative", "Asian and Asian-American Hermeneutics", "African Biblical Hermeneutics", "Bakhtin and Biblical Imagination Consultation", "Bible and Visual Arts", etc.

Cheryl Exum and Stephen D Moore have published an insightful introduction to the interaction of cultural studies with biblical studies, presented during the Third Sheffield Colloquium in April 1997.22 After providing a concise review of the British roots of cultural studies beginning in the 1950s they appraise the main concerns during the following 40 years $^{23}$ and then focus upon the intersection with biblical studies. They suggest that cultural

21 Telford, "Modern Biblical Interpretation," 2:438. Other approaches focusing predominantly upon the historical aspect of Scripture - according to Telford - include: textual criticism; historical criticism; tradition criticism; source criticism; form criticism; redaction criticism; history of religions approach; history of ideas; history of interpretation; history of reception; social-scientific approaches; anthropological approaches; sociocultural approaches; sociological approaches; socio-historical approaches; socio-political approaches; and psychological approaches.

22 J Cheryl Exum and Stephen D Moore, "Biblical Studies/Cultural Studies," in Biblical Studies/Cultural Studies. The Third Sheffield Colloquium (ed. J Cheryl Exum and Stephen D Moore; JSOTSup 266/Gender, Culture, Theory 7; Sheffield: Sheffield Academic Press, 1998), 19-45.

23 They suggest that the 1960s and 1970s were characterized by the founding of the important Centre for Contemporary Cultural Studies at the University of Birmingham. Generally, the 1960 s were seen as the "golden age" of cultural studies, whereas the 1970s introduced the Marxist phase of the movement (which was in unison with other academic programs at that time). This period, reaching the 1980 s also involved the 
studies (or criticism) are foremost an interdisciplinary approach that is "concerned with the Bible as culture and the Bible in culture, ancient and modern." ${ }^{24}$ More detailed they state that...

Biblical Studies/Cultural Studies is not just the Bible influencing culture or culture reappropriating the Bible, but a process of unceasing mutual redefinition in which cultural appropriations constantly reinvent the Bible, which in turn constantly impels new appropriations, and biblical scholars find themselves, in their professional capacity, haunting video stores, museums, and other sites of cultural production [emphasis supplied]. ${ }^{25}$

There are some new elements in this definition that provide further illumination in the quest to describe and understand the emerging phenomenon of cultural criticism. According to this view culture and Bible both are constantly interacting and cultural developments "reinvent" the Bible. A similar train of thought is present in Robert P Carroll's discussion of the Bible as a commodity, where he focuses upon the new Bible "versions" that contemporary culture has spawned, such as Children's Bible, the Bible as Bestseller, the Family Bible, the Gideon Bible, the Marriage Bible, The Woman's Bible, The Personal Growth Study Bible, etc. ${ }^{26}$

In my more detailed discussion of cultural criticism ${ }^{27}$ I reviewed more closely two studies undertaken from the perspective of cultural criticism, namely Philip Esler's discussion of mental disease and health in the Saul narrative in 1 Samuel $8-31,{ }^{28}$ and Fernando Segovia's comparison of "scientific criticism" (i.e., traditional historical criticism) and inter-cultural criticism, ${ }^{29}$ which focused upon the international, globalizing, reader-focused and equalizing qualities of the method. I observed four important characteristics of cultural criticism that are worth repeating here: First, cultural criticism is not (yet) a fully developed hermeneutical method. It is fragmented and lacks a unified definition. However, this fragmentation needs to be understood against the backdrop of postmodernism and its lack (and even antipathy) of absolutes. As a matter of fact, the diversity of methods and the lack of hermeneutical unity of cultural criticism is part and parcel of the ideological substructure. Second, cultural criticism is characterized by a fascination with and reaction to culture which is the most important point of reference. This statement appears to be a no-brainer (after all, we are talking about "cultural criticism"). However, the radical hermeneutical repercussions of this preference need to be appreciated. Third, cultural criticism is not necessarily interested in establishing the meaning of the text in its original historical context. As a matter of fact, ancient history (as opposed to recent history) is not of great interest for the practitioners of this method. Fourth,

growing interest in feminist, race and ideological research in connection with cultural studies. The interest in race and ethnicity continued into the 1990 s, which were also characterized by a vigorous internationalization of the movement, including major curriculum advances in the US academic system during the past 10 years. See here ibid., 19-32.

24 Ibid., 34.

25 Ibid. 35. The italics are mine.

26 Robert P Carroll, "Lower Case Bibles: Commodity Culture and the Bible," in Biblical Studies/Cultural Studies. The Third Sheffield Colloquium (ed. J Cheryl Exum and Stephen D Moore; JSOTSup 266/Gender, Culture, Theory 7; Sheffield: Sheffield Academic Press, 1998), 46-69.

27 See Klingbeil, "Cultural Criticism and Biblical Hermeneutics," 261-77.

28 Philip F Esler, "The Madness of Saul: A Cultural Reading of 1 Samuel 8-31," in Biblical Studies/Cultural Studies. The Third Sheffield Colloquium (ed. J Cheryl Exum and Stephen D Moore; JSOTSup 266/Gender, Culture, Theology 7; Sheffield: Sheffield Academic Press, 1998), 220-62.

29 Fernando F Segovia, "Reading-Across: Intercultural Criticism and Textual Posture," in Interpreting Beyond Borders (ed. Fernando F Segovia; The Bible and Postcolonialism 3; Sheffield: Sheffield Academic Press, 2000), 59-83. 
cultural criticism is focusing upon meanings in specific contexts, not on meaning (in the singular). Thus, the interpretation of a biblical text read in post-Soviet Russia will differ significantly from a text read in poverty stricken Guatemala or in war-torn Chechnya. Cultural criticism seeks to respond to these societal/cultural needs (as other ideologically aligned hermeneutical endeavors, such as feminist criticism or liberation theology criticism or poststructuralist criticism, also seek to do).

\section{God-talk and Metaphors: God as a Warrior}

God-talk is essential to biblical texts and theological discourse. The Bible's talk about God is manifold, often diverse, but always consistent, employing distinct genres such as hymns,${ }^{30}$ laments, prophetic discourse, ritual, ${ }^{31}$ law, narratives, and others. Metaphors are often employed in these texts to communicate conceptually a particular understanding and as such represent an important recourse to communicate something that is truly "out of this world," but at the same time is so deeply connected to humanity as the creator God of the Hebrew Bible who elects a people and frees them out of bondage and slavery in order for them to reach out by example, word, and deed to the "world" (= nations) around them. In a study of the metaphors contained in the Epistle to the Ephesians I have reviewed current theoretical reflection about metaphors per se and will include here a brief summary of the main characteristics and possibilities: ${ }^{32}$ (1) Metaphors are a much more complex literary device than previously thought and need to be read by looking simultaneously at meaning and usage. (2) Metaphors in theological texts (especially when talking about God) presuppose not only rationality, but also an experimental response (= faith) to that metaphor if to be understood adequately. (3) The understanding of metaphors presumes a thorough knowledge of the author's cultural, social, and contextual circumstances and his/her worldview. (4) Metaphors lend themselves to a multiplicity of meanings, which makes a fruitful intertextual (= use and re-use of motifs in different biblical books separated by time and/or geography) usage more probable. (5) Due to the polyvalence of metaphors, tensions can arise in the (ancient and modern) reader who sometimes can identify with the metaphor or may feel alienated/estranged requiring a reorientation of an earlier position. In this sense metaphors are important rhetorical tools.

Particularly, the second point of the characteristics of metaphors, i.e., the experimental response (= faith), is surprising, and connects neatly with the focus on the God-talk of

30 Compare the discussion of divine metaphors in the psalms and their relevance for the Gottesfrage in the times of the Hebrew Bible in Martin G Klingbeil, " 'De lo profundo, Jehová, a ti clamo.' Conocer al Dios de Israel a través del himnario veterotestamentario," in Pensar la iglesia hoy: hacia una eclesiología adventista. Estudios teológicos presentados durante el IV Simposio Bíblico Teológico Sudamericano en honor a Raoul Dederen (ed. Gerald A Klingbeil, Martin G Klingbeil and Miguel Ángel Núñez; Libertador San Martín: Editorial Universidad Adventista del Plata, 2002), 41-56.

31 I have argued for the theological potential of ritual texts in Gerald A Klingbeil, "Altars, Ritual and Theology Preliminary Thoughts on the Importance of Cult and Ritual for a Theology of the Hebrew Scriptures," Vetus Testamentum 54 (2004):495-515.

32 See Gerald A Klingbeil, "Metaphors and Pragmatics, 274-80, for additional bibliography. Earlier important studies dealing with metaphor theory include Peter W Macky, The Centrality of Metaphors to Biblical Thought. A Method for Interpreting the Bible (Studies in the Bible and Early Christianity 19; Lewiston: Edwin Mellen, 1990) and also Martin G Klingbeil, Yahweh Fighting from Heaven. God as a Warrior and as God of Heaven in the Hebrew Psalter and Ancient Near Eastern Iconography (OBO 169; Fribourg: University Press/Göttingen: Vandenhoeck \& Ruprecht, 1999), 9-37. The issue of divine metaphors is not only discussed in theological research but is also visited time and again in linguistics. See, for example, more recently, Mary Therese DesCamp and Eve E Sweetser, "Metaphors for God: Why and How Do our Choices Matter for Humans? The Application of Contemporary Cognitive Linguistics Research to the Debate on God and Metaphor," Pastoral Psychology 53 (2005):207-38. 
Scripture. For the present study one particular biblical metaphor, namely the God as a Warrior metaphor will be examined. Numerous studies have sought to understand this challenging metaphor ${ }^{33}$ and now is not the time and place to review them all. The God as a warrior metaphor appears $41 \times$ in the Hebrew Psalter (even though it may be seen also in the God of heaven metaphor that is often associated with it), predominantly in the first and second book, ${ }^{34}$ which may suggest an important diachronic development and may reflect distinct historical Sitz im Leben. ${ }^{35}$ Since the focus of this study does not attempt a discussion of the particular textual characteristics of this biblical metaphor, attention will be given to how scholars employing cultural criticism would most likely "appreciate" this biblical metaphor. In the following section I will focus on one of the essential qualities of the God as a warrior metaphor, namely its link to war, violence, conflict and bloodshed and will try to gage how postmodern scholarship (especially those scholars who employ cultural criticism as a valid tool of linking the triangle of world, theology, and faith) tries to come to grips with the biblical basis for these elements of the divine metaphor and their impact on current theology and ethics.

The issue of war in the Bible has often been discussed in biblical scholarship. ${ }^{36}$ Scholars trying to reconcile modern notions of justice and ethical behavior have struggled with issues such as the authority of Scripture, the complete annihilation of cities, families or

33 Most of the studies about the divine warrior focus on texts of the Hebrew Bible, as for example (in chronological order): Tremper Longman III and Dan G Reid, God is a Warrior (Studies in Old Testament Biblical Theology; Grand Rapids: Zondervan, 1995); Marc Zvi Brettler, "Incompatible Metaphors for YHWH in Isaiah 40-66," Journal for the Study of the Old Testament 78 (1998):97-120; Susan M Pigott, "The Kingdom of the Warrior God: The Old Testament and the Kingdom of Yahweh," Southwestern Journal of Theology 40.2 (1998):5-20; Martin G Klingbeil, Yahweh Fighting from Heaven; Paul Kalluveettil, "The Warrior God and the Prince of Peace: Biblical Perspectives on War and Peace," Journal of Dharma 27 (2002):291-308; Richard D Nelson, "Divine Warrior Theology in Deuteronomy," in A God So Near. Essays in Old Testament Theology in Honor of Patrick D Miller (ed. Brent A Strawn and Nancy R Bowen; Winona Lake: Eisenbrauns, 2003), 241-59; and Alec Basson, "Divine Metaphors in Psalm 35 Explored from a Cognitive Anthropological Perspective," Old Testament Essays 18 (2005):9-21. Occasionally, the topic is also discussed from the perspective of the New Testament. Cf. Paul Brooks Duff, "The March of the Divine Warrior and the Advent of the Greco-Roman King: Mark's Account of Jesus' Entry into Jerusalem,' Journal of Biblical Literature 111 (1998):55-71.

34 See Martin G Klingbeil, Yahweh Fighting from Heaven, 36. The references are Pss 3:4, 8 [2×]; 5:13; 7:11; $10: 15 ; 17: 13 ; 18: 3,31 ; 21: 9,10[2 \times], 13[2 \times] ; 35: 1[2 \times], 2[2 \times], 3 ; 38: 3 ; 46: 8[2 \times], 9,10[4 \times], 12[2 \times] ; 58: 7 ;$ $59: 12 ; 64: 8 ; 68: 8[2 \times], 15,18,22 ; 76: 4[4 \times]$.

35 Compare also the pertinent remarks in Martin G Klingbeil, "Metaphors That Travel and (Almost) Vanish: Mapping Diachronic Changes in the Intertextual Usage of the Heavenly Warrior Metaphor in Psalms 18 and 144" (paper presented at the Annual Meeting of the European Association of Biblical Studies, Dresden, Germany, August 9, 2005). The study is scheduled to appear in a collection of essays focusing on metaphors in the Psalms that will be published by Peeters.

36 Some relevant more recent discussions include: Gwilym H Jones, "The Concept of Holy War," in The World of Ancient Israel: Sociological, Anthropological and Political Perspectives (ed. Ronald E Clements; Cambridge: Cambridge University Press, 1991), 299-321; Norbert Lohfink, “'Holy War' and the 'Ban' in the Bible," Theology Digest 38 (1991):109-14; Michael Walzer, "The Idea of Holy War in Ancient Israel," Journal of Religious Ethics 20 (1992):215-28; Rolf P Knierim, "On the Subject of War in Old Testament and Biblical Theology," Horizons in Biblical Theology 16 (1994):1-19; J Holloway, "The Ethical Dilemma of the Holy War," Southwestern Journal of Theology 41.1 (1998):44-69; Eckart Otto, Krieg und Frieden in der Hebräischen Bibel und im Alten Orient (Theologie und Frieden 18; Stuttgart: Verlag W Kohlhammer, 1999); Thomas L Thompson, "Holy War at the Center of Biblical Theology: Shalom and the Cleansing of Jerusalem," in Jerusalem in Ancient History and Tradition (ed. Thomas L Thompson; Journal for the Study of the Old Testament Supplement Series 381/Copenhagen International Seminar 13; London: T \& T Clark, 2003), 223-57; Walter Dietrich and Moisés Moyordomo, Gewalt und Gewaltüberwindung in der Bibel (Zürich: Theologischer Verlag Zürich, 2005). 
tribes (i.e., ban), ${ }^{37}$ or the justification of violence and oppression, to name just a view. Over the past millennia most wars had some religious component(s) or were motivated by religious zeal. Crusaders, religious wars during and following the Protestant reformation in Europe, World War I and II ("In God we trust!"), Islamic Jihad, ${ }^{38}$ and other religiously motivated warfare (or terrorism, depending from whose side one is standing) all used religious elements in their justification of war, often referring back to the biblical motifs of "holy war" and "God as a warrior fighting for his people". A brief review of more recent studies about the subject seems to confirm the prevalence and importance of (current) culture that is used to interact with and evaluate the biblical metaphor of the divine warrior. A few examples should suffice here: Humphrey Fisher discusses the biblical concept of booty taken in holy war and compares it cross-culturally to similar phenomena in black Muslim Africa. ${ }^{39}$ In 2003, well-known Yale University professor John J Collins discusses the ethics of violence, even divine violence, against the larger context of the image of God that the Bible portrays. ${ }^{40} \mathrm{He}$ suggests that sometimes we may have to read and read again until a reading is found that is ethically and socially acceptable. While Collins is generally considered a main-stream critical scholar, the concerns raised in his study reflect the concerns of cultural criticism. A couple of years before Collins, Amélie Kuhrt published a fascinating study about women and war in the ANE. ${ }^{41}$ The interaction between feminist concerns and cultural and social concerns would suggest a broad understanding of cultural criticism, affecting also areas such as feminist criticism. A final example comes from a study of war imagery in Southern Baptist texts, images, and art during the time of | the Confederacy, which often employed biblical reasoning to support the cause of the Confederacy. ${ }^{42}$

As can be easily perceived from this brief review of some relevant recent studies involving the holy war concept with God as a Warrior language, modern readers (and particularly scholars that look at the biblical text through the lens of contemporary or ancient culture[s]) are either ignoring the topic or are extremely critical towards the use of the biblical motif. This is most likely caused by society's critical stance towards the justification of war on religious grounds. If and when the issue is tackled most interpreters would either prefer to discuss the ethical implications of the biblical concept or focus

37 The literature on the biblical ban is also quite extensive. Some important recent contributions include Philip D Stern, The Biblical ঢērem. A Window on Israel's Religious Experience (Brown Judaic Studies 211; Atlanta: Scholars Press, 1991); Lohfink, "'Holy War' and the 'Ban' in the Bible,” 109-14; Christa SchäferLichtenberger, "Bedeutung und Funktion von $\sim$ r,xe in biblisch-hebräischen Texten," Biblische Zeitschrift 38 (1994):270-75; Allan Bornapé, "El problema del r,xe en el Pentateuco y su dimensión ritual," DavarLogos 4 (2005):1-16. Comparative data from othe ANE sites and cultures have also been discussed in this particular context. Cf. Michaël Guichard, "Les Aspects Religieux de la Guerre a Mari," Revue d'assyriologie et d'archéologie orientale 93 (1999):27-48, and linking both biblical and ANE data, Daniel E Fleming, "The Seven-Day Siege of Jericho in Holy War," in Ki Baruch Hu. Ancient Near Eastern, Biblical, and Judaic Studies in Honor of Baruch A. Levine (ed. Robert Chazan, William W Hallo and Lawrence H Schiffman; Winona Lake: Eisenbrauns, 1999), 211-28.

38 A cross-cultural study of holy war in the biblical and the qu'rānic tradition has been undertaken by Reuven Firestone, "Conceptions of Holy War in Biblical and Qu'rānic Tradition," Journal of Religious Ethics 24 (1996):99-123.

39 Humphrey J Fisher, "Booty Taken in Holy War: A Cross-Cultural Perspective: The Bible, and the History of Muslim Black Africa," Theology 105 (2002):273-83.

40 John J Collins, "The Zeal of Phinehas: The Bible and the Legitimation of Violence," Journal of Biblical Literature 122 (2003):3-21.

41 Amélie Kuhrt, "Women and War," NIN. Journal of Gender Studies in Antiquity 2 (2001):1-25.

42 David Chesebrough, "A Holy War: The Defense and Support of the Confederacy by Southern Baptists," American Baptist Quarterly 6.1 (1987):17-30. 
exclusively on the reasons for the use of this motif in the biblical text and the historical Sitz im Leben that must have given rise to this particular use.

In the following paragraphs a summary of the presuppositions of cultural criticism as a recent (and increasingly prominent) empirical tool that seeks to connect theology with the world will be given. Clearly, cultural criticism is here to stay. The increasing number of publications (both in monographic series and journals) focusing either partially or entirely on the major concerns of the method, as well as the numerous sections, groups or consultations of the annual SBL congress demonstrate that truism. Looking at the philosophical presuppositions underlying this approach, the need to be relevant and be able to provide tangible answers without having to opt for the answer is a heritage of postmodernism. Supposed objectivity is not aimed for, and, as a matter of fact, cannot be attained, since it is a relict of a modernist positivistic worldview. Cultural criticism also emphasizes dialogue since no absolutes exist and can also allow for partial readings or solutions. Cultural criticism wishes to empower those that are seldom heard and give them a voice (although it must be said that even the avant-garde sections, groups and consultations at the SBL annual meetings generally are dominated by established scholars working mostly at US [or to a lesser degree European] Universities). Thus, it aims to be an "interpretation from below," where academic hierarchy or existing power structures should be challenged.

It is quite obvious from the outset of this summary that cultural criticism has shed most of the basic principles of mainstream traditional biblical hermeneutics. ${ }^{43}$ One does not find discussions about classical issues in hermeneutics such as inspiration or revelation of Scripture. Equally, the authority, unity or even limits of Scripture (= canon) are not of great concern to practitioners of cultural criticism. While reading studies focusing upon or employing cultural criticism, one often has the impression that a new vocabulary is being created with a very limited connection to earlier hermeneutical discussions. There seems to be method in this, since it underlines the diametrically opposed philosophical presuppositions so important to hermeneutics. Cultural criticism is open for dialogue, but it is mostly a dialogue among equals. It is hard to find examples of fruitful (and not just one-sided) interaction between cultural criticism and traditional hermeneutics (be it historical-critical or historical-grammatical approaches). ${ }^{44}$

Cultural criticism grew out of concerns connected with the history of religion and comparative religion paradigms. Since it does not aim for "truth" or "exclusivity" it is very interested in comparative cross-pollination with other world religions, although it still focuses upon the Bible. In conclusion of this section: cultural criticism has moved the point of

43 Including concepts such as revelation, inspiration, sola Scriptura, tota Scriptura, the Bible as its own interpreter, the canon of Scripture, the unity of Scripture, the authority of Scripture, etc. See here, for example, Gerhard Maier, Biblical Hermeneutics (trans. RW Yarbrough; Wheaton: Crossway Books, 1994), or Gerhard F Hasel, "General Principles of Interpretation," in A Symposium on Biblical Hermeneutics (ed. Gordon M Hyde; Washington, DC: Biblical Research Committee, General Conference of SDA, 1974), 163-93.

44 The only exceptions being perhaps Segovia, "Reading-Across: Intercultural Criticism and Textual Posture," although he is mainly interested in juxtapositioning the different approaches. See here also my comments in Gerald A Klingbeil, review of Heikki Räisänen et al., Reading the Bible in the Global Village: Helsinki, Journal of Near Eastern Studies 63 (2004):140, where I wrote: "The present volume provides an important diagnostic of where biblical hermeneutics and theology stand and which questions, issues and perspectives need to inform the 21 st century interpreter. However, it is not a dialogue. The general tone is one of a manifesto or apologetic document (the exception being Stendahl's short contribution) and one wonders if biblical scholars will ever be able to listen to one another with the readiness to change. It appears that our own stories, paths and presuppositions are just so strong that they dim the story, path and presupposition of the biblical text." 
reference from the text towards the reader and his/her culture. In this, it follows other modern hermeneutical paradigms, such as Reader-Response Criticism, Feminist Criticism, etc.

\section{From God-talk to Hermeneutics: What can Cultural Criticism contribute to Biblical Hermeneutics?}

How can biblical scholars and teachers navigate this Bermuda triangle of world, theology, and faith $?^{45}$ As already noted, the test-case of the recent empirical method of cultural criticism has demonstrated that superimposing an external model over the biblical text does not provide an adequate solution to the complex issue. In reality, it appears to throw millennia of interaction with the biblical text into the trash can, since there is no meaningful communication between traditional hermeneutics and this avant-garde model of biblical interpretation. However, the main concern behind cultural criticism of achieving more relevance is important and should not be forgotten. Cultural criticism reminds us that Scripture was not designed to be read in ethereal cathedrals but was produced because of a real need (just think of the ministries of the classical prophets, or Ezra or Nehemiah, to mention just a few). Cultural criticism is also a very powerful reminder that we should not mistake our predominantly Western worldview and its underlying cultural paradigm for the worldview and reality of the biblical authors in ancient times. This point has become increasingly important to me personally, since I have spent the last 20 years studying, living, teaching, and preaching in parts of the world which do not share many of the basic tenets of a Western worldview, which is (unfortunately) also reflected in the way we read Scripture.

Another positive side effect of cultural criticism is its focus on the incarnational quality of the Word. Christ did not come to this planet in a clean room of an ultra-modern CPU factory without any contact or contamination with his world and culture. To the contrary: he became a baby, born into a family of the lower ranks of society, being poor, being powerless, but bringing salvation. Cultural criticism also reminds us the God's Word can (and must!) speak meaningfully to people in distinct cultural contexts and thus provides important impetus to our missiological questions and strategies.

Although there are these obvious positive side-effects of cultural criticism, one should also be aware of the presuppositions and concepts when thinking about modern empirical methods (and more to the point, cultural criticism): First, cultural criticism has a problem with authority. There is no final "correct" reading, no ultimate answer exists. Clearly, this negates the inherent nature of Scripture being the Word of God, which carries authority. Second, cultural criticism seems to have a blind spot (as we all do) concerning history. The reality of the past is of the utmost importance for our understanding of Scripture now, since the Word was revealed in time and in specific circumstances. Questioning or ignoring that historical moment will ultimately lead to theological relativism, which is what practitioners of cultural criticism seem to strife for. It is this lack of absolutes that makes it possible that culture can become the all important lens through which the biblical text needs to be viewed. Third (and related to the earlier point), if there is only one way, one truth and one life (John 14:6), ${ }^{46}$ relativism cannot be part and parcel of our hermeneutical philosophical

45 Many of the thoughts expressed here were originally addressed to Seventh Day Adventist scholars. However, it is hoped that other biblical scholars interested in the interaction between world, faith, and theology may also benefit from these observations.

46 It should be noted that Jesus' statement in John 14:6 is primarily concerned with knowing the way to the Father and has been recognized as one of the classical formulations of the "Johannine doctrine of salvation that is based entirely on Jesus Christ" (Rudolf Schnackenburg, The Gospel According to St. John [3 vols.; Herder's Theological Commentary to the New Testament; London: Burns \& Oates, 1968-1982], 3:65). Among the three coordinates ("way, truth, and life") the "way" is contextually the most significant. The 
presuppositions. There are definite answers and Scripture is full of them. Fourth, cultural criticism seems to be stuck to its a priori presuppositions, which in turn does not allow it to enter into a "real" discussion with traditional hermeneutics. It speaks another language and perhaps does not even want to interact. In this sense it is contradictory to its own premises, which emphasize dialogue and interaction.

As already observed by specialists of metaphor theory, theological metaphors and Godtalk cannot be only academic or theoretical, but requires an existential and experimental component, which we may call "faith." 47 It is this faith that helps me to communicate theology to the world, and not primarily the empirical models which seem to be prone to fashions and fads. ${ }^{48}$ Biblical interpretation should not just bracket out (or even ignore) texts that are uncomfortable to our current worldview or cultural context. The principles of biblical interpretation, and particularly biblical interpretation in the context of a faith community, cannot (and should not) come from an outside model, but rather should emanate from the biblical text itself. ${ }^{49}$ Once this presupposition is agreed upon one can note immediately that both the Hebrew Bible as well as the New Testament do not exist in splendid isolation, but always seem to be in dialogue with the world. However, it is not on the terms of the "world" that this dialogue is taking place, but rather on the terms of the revealed will of God. It is the existential interaction (both individually as well as in community) with this divine revelation that will provide a critical filter for changing empirical methods.

important introductory $\gamma \varepsilon \mu \mathrm{l}$ "I am," and the use of the definite Greek article both emphasize the absoluteness of Jesus' claim. Cf. George R Beasley-Murray, John (Word Biblical Commentary 36; 2d ed.; Dallas: Word Books, 1999), 252; and also Gerald L Borchert, John 12-21 (New American Commentary 25B; Nashville: Broadman \& Holman, 2002), 108-10.

47 Brigitte Seifert, Metaphorisches Reden von Gott im Hoseabuch (Forschungen zur Religion und Literatur des Alten und Neuen Testaments 166; Göttingen: Vandenhoeck \& Ruprecht, 1996), 77, uses the German "Vertrautheit" to indicate this intimacy.

48 One should just review the history of dominant research methods over the past 50 or 100 years to note these "fashion trends".

49 This has also be suggested repeatedly in the research of Fernando Canale and his student Raúl Kerbs. Both approach the important methodological issue from two distinct perspectives. While Canale is a specialist in philosophical and systematic theology, Raúl Kerbs specialized in philosophy and received his doctorate from the department of philosophy of a renowned Argentinean university. Cf. (in chronological order), Fernando L Canale, "Revelation and Inspiration: The Ground for a New Approach," Andrews University Seminary Studies 31 (1993):91-104; idem, "Revelation and Inspiration: Method for a New Approach," Andrews University Seminary Studies 31 (1993):171-94; idem, "Interdisciplinary Method in Christian Theology? In Search of a Working Proposal," Neue Zeitschrift für Systematische Theologie und Religionsphilosophie 43 (2001):366-89; Kerbs, "El método histórico-crítico en teología: en busca de su estructura básica y de las interpretaciones filosóficas subyacentes (parte I);" idem, "El método histórico-crítico en teología: en busca de su estructura básica y de las interpretaciones filosóficas subyacentes (parte II);” idem, Raúl Kerbs, "La crítica del Pentateuco y sus presuposiciones filosóficas," in Inicios, fundamentos y paradigmas: estudios teológicos y exegéticos en el Pentateuco (ed. Gerald A Klingbeil; Serie monográfica de estudios bíblicos y teológicos de la Universidad Adventist del Plata 1; Libertador San Martín: Editorial Universidad Adventista del Plata, 2004), 3-43. 